\title{
The identity of Sellaphora bacillum (Ehrenberg) D.G. Mann
}

\author{
Regine JAHN ${ }^{1}$, David G. MAnN², Katharine M. Evans² \& Aloisie PoulíčKovÁ ${ }^{3}$ \\ ${ }^{1}$ Botanic Garden and Botanical Museum Berlin-Dahlem, Freie Universität Berlin, Königin-Luise-Str. 6-8, 14195 \\ Berlin, Germany. \\ ${ }^{2}$ Royal Botanic Garden Edinburgh, 20A Inverleith Row, Edinburgh EH3 5LR, Scotland, UK \\ ${ }^{3}$ Department of Botany, Faculty of Science, Palacký University, CZ-771 46 Olomouc, Czech Republic
}

\begin{abstract}
A lectotype and epitype are designated for the freshwater epipelic diatom Navicula bacillum EHRENBERG, now generally referred to as Sellaphora bacillum (EHRENBERG) D.G. MANN. The lectotype is an original drawing preserved in the EHRENBERG collection at the Museum für Naturkunde in Berlin, which shows a naviculoid diatom with linear valves and rounded poles. This is consistent with the current concept of $S$. bacillum and with usage during the last 160 years but the lectotype shows insufficient detail to constrain the use of the epithet it defines. We therefore support the lectotype with an epitype, which is the preserved material of a clone (referred to as BLA4 in previous publications) from Blackford Pond, Scotland, for which a DNA barcode is available (the cox 1 sequence deposited as GenBank EF164941). We illustrate both the epitype and the natural S. bacillum population from which BLA4 was derived.
\end{abstract}

Key words: Bacillariophyta, diatoms, DNA barcode, nomenclature, Sellaphora, taxonomy, typification

\section{Introduction}

In 1989, MANN proposed the new combination, Sellaphora bacillum (EHRENBERG) D.G. MANN; however, rather than cite the first basionym of Navicula bacillum EHRENBERG 1839, MANN cited EHRENBERG's Navicula bacillum of 1843. In his comprehensive paper on the diatoms of the Americas (1843), EHRENBERG summarized many of his organisms, often picturing them for the first time as he did with $N$. bacillum and providing Latin descriptions, making them look like first descriptions. Although EHRENBERG notes in the 1843 text that only the names with an asterisk are described as new, this was not noticed by subsequent researchers, in some instances not even by himself.

In our efforts to typify EHRENBERG's names, to stabilize their use and to tie data from the living cell to names for future research, we came across this discrepancy and decided to combine our efforts in order to present to the scientific community a valid and typified name, which has a taxonomic concept that includes molecular and cytological information as well as morphological data for the valve.

Microscopy was as described by MANN et al. (2008).

\section{Observations and Discussion}

Sellaphora bacillum (EHRENBERG) D.G. MANN

Combination made by MANN (1989, p. 2).

Basionym: Navicula bacillum EHRENBERG in Abh. Königl. Akad. Wiss. Berlin, 1838: 130 (1839).

[Not Navicula bacillum EHRENBERG 1843; this was a bibliographic error in MANN's (1989) citation of the basionym]

Lectotypus (designated here): EhrenBerg's drawing Nr. 2275 (a detail is presented here as Fig. 1a) (BHUPM herbarium, Museum für Naturkunde, Berlin).

Locus typicus: fossil (Kreidemergel); drawing 2275 is from Oran, Africa.

EHRENBERG's (1839) diagnosis reads: “N. Bacillum, striata, testula lineari-oblonga utrinque rotundata, apertura media magna longitudinaliter oblonga. $N$. viridi juvenili affinis." Although EHRENBERG does not present a size nor publish a figure (unlike several other species published as new in the 1839 work, which were illustrated), the diagnosis is valid. In order to find the sample to be searched for Navicula bacillum we checked his table (Übersicht der Hauptformen der dem blossen Auge unsichtbaren constituirenden Organismen) and found three localities - Caltanisetta (Sicily), Oran (Algeria) and Greece Nr. 5 - for which he recorded $N$. bacillum. The samples and drawings for these localities were examined in the EHRENBERG collections in Berlin. Unfortunately, none of the labels of the mica of these samples show the name Navicula bacillum, nor do the drawings cross-reference to the mica as they do in a number of other instances. Only 
the drawing Nr. 2275 from Oran has an outline of a valve with the name Navicula bacillum beneath it. This is the only guide to EHRENBERG's original concept of $N$. bacillum and we therefore specify this drawing (Fig. 1) as the lectotype. Since this drawing is not interpretable (beyond that it shows a linear naviculoid diatom with rounded poles), and because a current concept of this taxon exists, we also designate an epitype, which encompasses all the data needed for modern taxonomic research.

Epitypus (designated here to support the lectotype specified above): clone BLA4 (= SEL438B, isolated 5 June 2003 by Victor Chepurnov), preserved as a cleaned preparation of cell walls on slide E3640 (Royal Botanic Garden Edinburgh), which is mounted in Naphrax. A cox 1 DNA barcode is available for clone BLA4, as GenBank accession EF164941 (EvAns et al. 2007) and is also designated part of the epitype; an $r b c \mathrm{~L}$ sequence for the same clone is available as GenBank EF143311. Two valves from E3640 are illustrated here (Fig. 2a, b), as are representative valves from natural populations of $S$. bacillum from Blackford Pond, Edinburgh, from which BLA4 was isolated (Fig. 2c-f). The ultrastructure, chloroplasts and mating of Blackford S. bacillum have been illustrated by MANN (1989, figs 2, 13, 14, 39 and 40).

Locus epitypicus: epipelon in fine mud under 30-50 $\mathrm{cm}$ water at the SW end of Blackford Pond, Scotland (United Kingdom National Grid Reference NT253708), a small eutrophic freshwater lake.

We could not find any authenticated specimens to show what EHRENBERG intended when he first described Navicula bacillum in 1839 . The other organisms drawn by EHRENBERG from the Oran sample are principally marine, including Grammatophora (Fig. 1a, top right), Actinocyclus, Actinoptychus, Biddulphia and silicoflagellates. On the other hand, there is a drawing that seems to show Terpsinoë (Fig. 1a, bottom), generally regarded as a brackish or freshwater genus (e.g. Round et al. 1990, p. 256), and also a naviculoid diatom labelled 'Navicula ventricosa' (not illustrated), which strongly resembles the freshwater diatom known today either as Caloneis ventricosa (EHRENBERG) MEISTER or C. silicula (EhrenberG) Cleve. In our opinion, contamination of a marine deposit by freshwater diatoms, either before deposition or during sampling and sample preparation, is plausible. In contrast, the Kotzebue (Mexico) material EHRENBERG used to produce the image of $N$. bacillum for his treatise on American diatoms (1843, pl. 4, section v, fig. 8, reproduced here as Fig. 1b; the original drawing is reproduced in Fig. 1c, again as ' 8 ') is clearly of freshwater or subaerial origin, shown by the accompanying diatoms and testate amoebae (e.g. Fig. 1b, c), which include Eunotia, Hantzschia amphioxys (EHRENBERG) Grunow and Euglypha. It is unlikely that the same species could be autochthonous in both the Oran and Kotzebue samples. Indeed, it may be partly because of the difference in habitat that KÜTZING (1844) regarded the 1839 and 1843 'versions' of $N$. bacillum as independent taxa. KütZING transferred the unillustrated $1839 \mathrm{~N}$. bacillum to Diadesmis (though with some doubt: KütZING 1844, p. 109), whereas the 1843 specimen from Kotzebue was left in Navicula (op. cit., p. 96). This policy is nomenclaturally flawed, of course, because if the 1839 and 1843 versions of $N$. bacillum are regarded as independent taxa, the 1843 taxon would be a later homonym, and hence illegitimate. In any case, choice of lectotype is limited to the material used as a basis for the 1839 publication.

The priority of the 1839 description is both a problem and an opportunity - a problem because there is no published illustration and no specimen to act as a lectotype, but an opportunity because the ambiguity of the 1839 account allows us to maintain established usage of Navicula (=Sellaphora) bacillum and so avoid unwelcome name changes. The current use of the epithet (e.g. Krammer \& Lange-Bertalot 1986, p. 187 and pl. 67 , figs 2, 3) has been consistent for a long time (e.g. Cleve \& Grunow 1880, p. 44, pl. 2, fig. 50; Hustedt 1930 , p. 280, fig. 465; PAtrick \& Reimer 1966, p. 494, pl. 47, fig. 4), having been established with clear illustrations by GRUNOw (1860, p. 551, pl. 2, fig. 1a, b). GRUNOW in turn cited SMITH (1856, p. 91), who referenced KüTZING (1844). SMITH's concept also seems to have conformed closely to the modern idea of $S$. bacillum, judging by his acceptance of the records of the species by GREGORY (1856), which, unlike SMITH's account, were illustrated. SMITH (op. cit.) also claimed that he had examined specimens sent to him by DE BRÉBISSON, apparently 'authenticated' by KüTZING or perhaps even by EhrEnBerG (SMITH's text says "Ehr. in Kütz. Bacill. xxviii. 69. ad specim. authen. quae dedit am. De Brébisson."). KüTZING's illustration of Navicula bacillum (1844, pl. 28, fig. 69) was a direct copy from Ehrenberg (1843, pl. 4, section v, fig. 8; our Fig. 1b) and measurements of it give dimensions of $43 \times 10 \mu \mathrm{m}$, agreeing with the current concept and epitype.

Hence the modern concept of $S$. bacillum can certainly be traced back to within a few years of EHRENBERG's original description and, in 


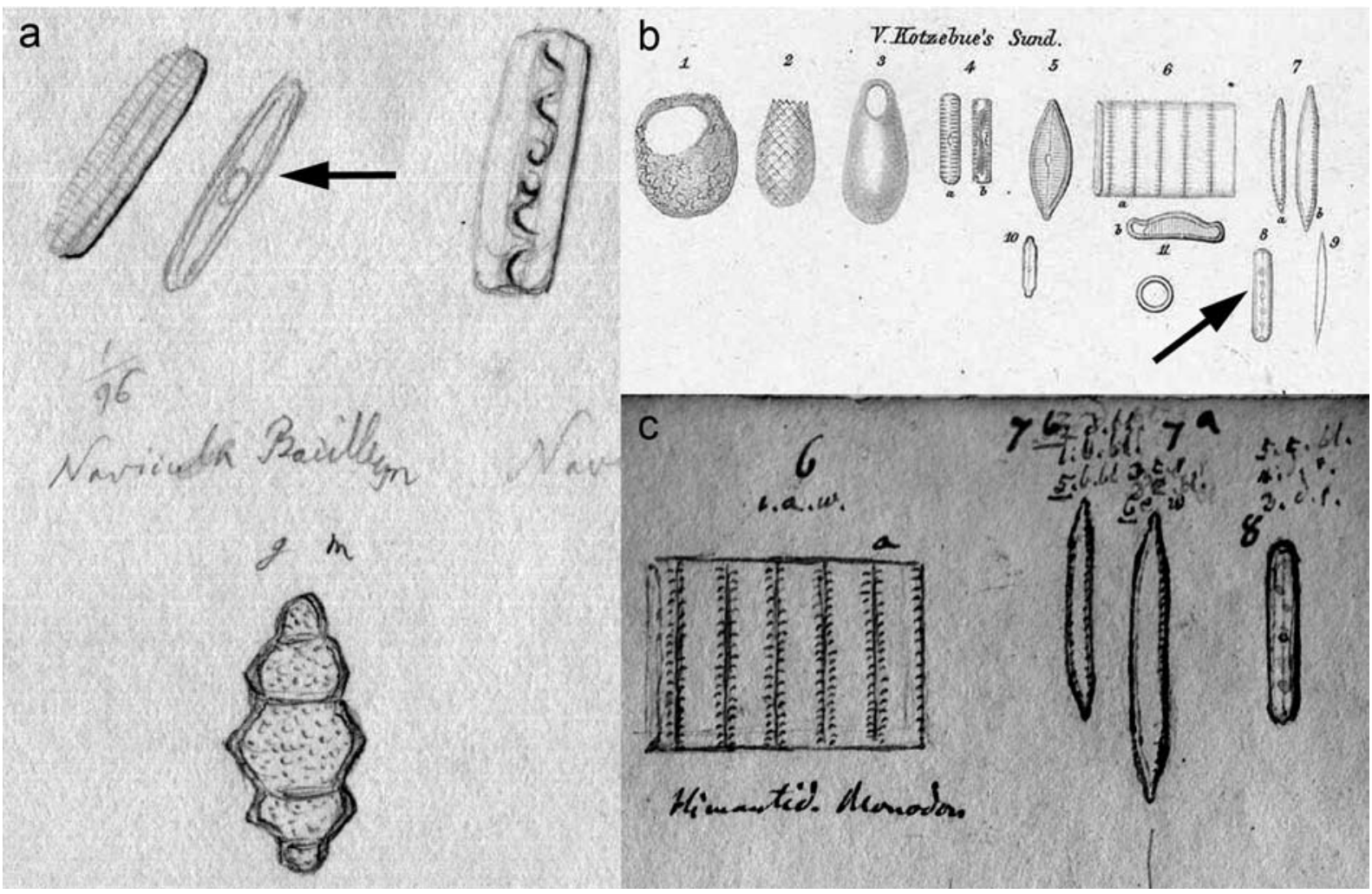

Fig. 1. Navicula bacillum EHRENBERG: (a) Detail of drawing \#2275 (BHUPM) from Oran, showing the lectotype of N. bacillum (arrow). LAZARUS \& JAHN's (1998) information about EHRENBERG's methods of recording allow us to estimate the dimensions of this specimen as c. $56 \times$ c. $10 \mu \mathrm{m}$. Also visible in this section of the drawing are Grammatophora (top right) and Terpsinoë (bottom). (b) Detail of EhrenBerg's illustrations of organisms from Kotzebue Sound (Ehrenberg 1843, plate 4, section v): $N$. bacillum is illustrated as fig. 8 (arrow). (c) Part of the sheet of original drawings (held in BHUPM) used to construct the 1843 plate shown in (c); again, N. bacillum is numbered ' 8 '. Following LAZARUS \& JAHN (1998), this specimen would measure 43 $\mu \mathrm{m}$ in length.

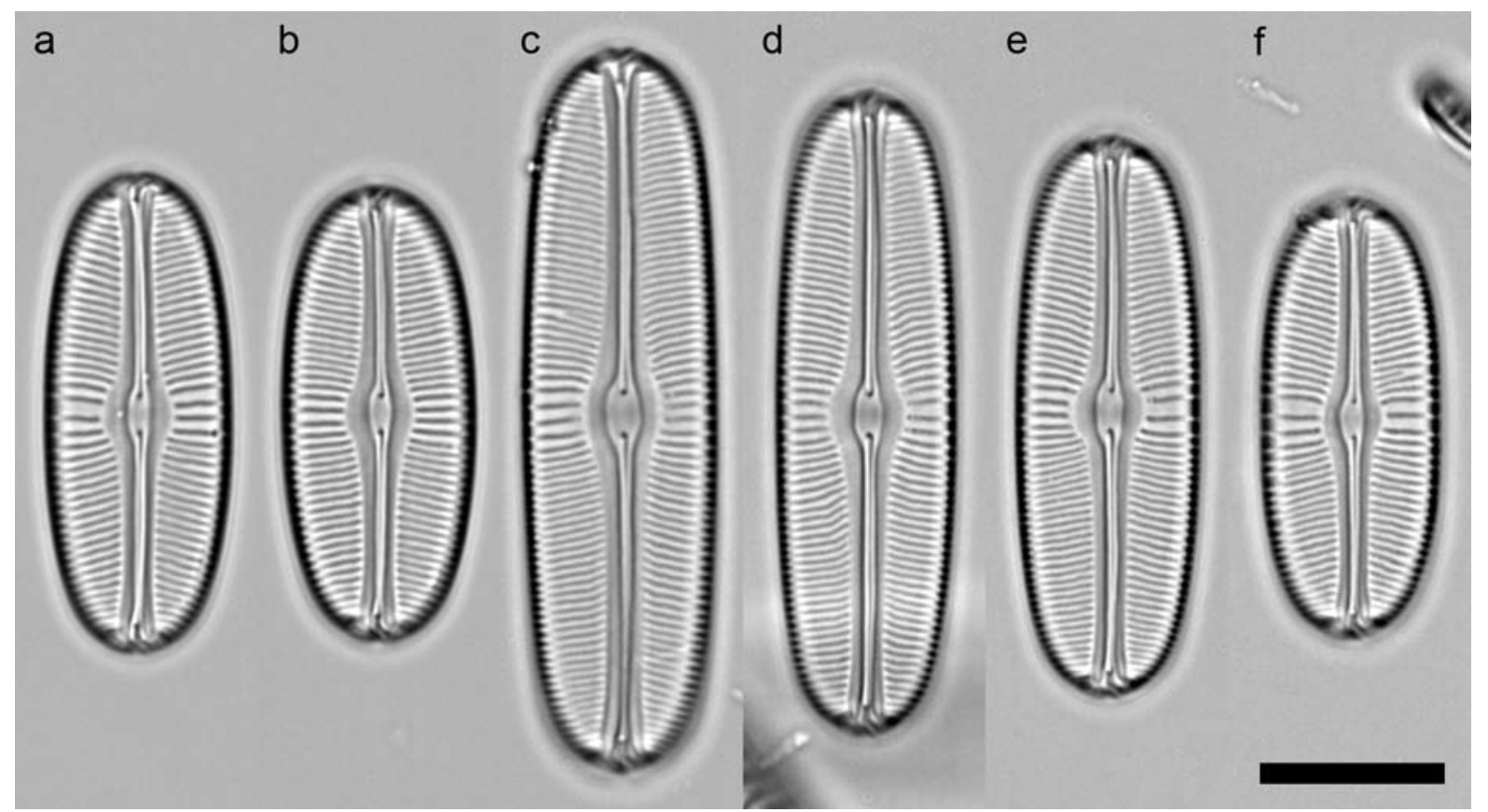

Fig. 2. Sellaphora bacillum: (a, b) - Epitype valves of clone BLA4 on slide E3640. (c-f) Valves showing stages in size reduction, from Blackford Pond slide "18.12.86 thin 1" (E). Scale bar $10 \mu \mathrm{m}$. 
the absence of specimens from any of the three localities listed by Ehrenberg (1839), there can be no proof that EHRENBERG would not also have identified diatoms like those shown in Fig. 2 as $N$. bacillum. We consider, therefore, that our choice of a drawing as the lectotype, and specification of a modern epitype associated with DNA barcode data, is the best way to achieve stability and precision in the nomenclature and taxonomy of this common freshwater diatom. A detailed description and further illustrations of the Blackford Pond population of $S$. bacillum are given by MANN et al. (2008, p. 29, fig. 5) as "Sellaphora [bacillum $\mathrm{K}-\mathrm{LB}] \Phi$ 'rectangular"'.

Description: Valves linear becoming linearelliptical, with smoothly rounded poles, 21.5$53 \mu \mathrm{m} \times 9.5-10.75 \mu \mathrm{m}$ (the length range is incomplete and will have to be extended when initial cells have been observed; the lectotype appears to have been slightly longer, at $56 \mu \mathrm{m}$, but this cannot be confirmed). Striae slightly radiate throughout, more widely spaced but with no intercalated striae at the centre, 19-24 in $10 \mu \mathrm{m}$; areolae invisible in LM (except occasionally a few areolae immediately adjacent to the central area). Axial area narrow, occupying c. $20 \%$ of the valve width near the centre, representing a depressed plain area covered by a narrow conopeum. Central area expanded in longer specimens (to $35-45 \%$ of the valve width), merging gradually into the axial area, \pm circular. Raphe-sternum well-defined because of the adjoining depressed area, narrow, expanded into a narrowly elliptical 'central nodule' surrounding the central raphe endings. Raphe very slightly sinuous. Polar bars present, parallel.

Known distribution: recorded by MANN et al. (2008, on the basis of morphology) from: Scotland: Balgavies Loch, Blackford Pond, Dunsapie Loch, Inverleith Pond, Loch Leven, Lochend Loch, Loch of Drumellie, Loch of Clunie, Monk Myre, Rae Loch, Threipmuir Reservoir; England: Burton Pond (Petworth), Cole Mere, Crose Mere, Kates Cottage Pond (Sturston). There are many other records in the literature that are likely to refer to this species, but all need to be confirmed.

\section{References}

Cleve, P. T. \& Grunow, A. (1880): Beiträge zur Kenntniss der arctischen Diatomeen. - K. svenska Vetensk.Akad. Handl. 17(2): 1-121.

EhrenberG, C. G. (1839): Über die Bildung der Kreidefelsen und des Kreidemergels durch unsichtbare
Organismen. - Abh. Königl. Akad. Wiss. Berlin, 1838: 59-147.

EhrenBerG, C. G. (1843): Verbreitung und Einfluss des mikroskopischen Lebens in Süd- und Nord-Amerika. - Abh. Königl. Akad. Wiss. Berlin, 1841(1): 291446.

Evans, K. M., Wortley, A. H. \& Mann, D. G. (2007): An assessment of potential diatom "barcode" genes ( $\operatorname{cox} 1$, $r b c \mathrm{~L}, 18 \mathrm{~S}$ and ITS rDNA) and their effectiveness in determining relationships in Sellaphora (Bacillariophyta). - Protist 158: 349-364.

Gregory, W. (1856): Notice of some new species of British fresh-water Diatomaceae. - Q. J. Microsc. Sci., new series, 4 : 1-14.

GRUNOw, A. (1860): Ueber neue oder ungenügend gekannte Algen. Erste Folge, Diatomeen, Familie Naviculaceen. - Verh. zool.-bot. Ges. Wien 10: 503-582.

Hustedt, F. (1930): Bacillariophyta. - In: PAscher, A. (ed.): Die Süsswasser-Flora Mitteleuropas 10/ 2: 1-466, G. Fischer, Jena.

Krammer, K. \& Lange-Bertalot, H. (1986): Bacillariophyceae 1. Teil: Naviculaceae. - In: EтTL, H., Gerloff, J., Heynig, H. \& Mollenhauer, D. (eds): Süsswasserflora von Mitteleuropa 2/1: 1-876 pp., G. Fischer, Stuttgart \& New York.

KÜTZING, F. T. (1844): Die kieselschaligen Bacillarien oder Diatomeen. - 152 pp., W. Köhne, Nordhausen.

LAZARUS, D. \& JAHN, R. (1998): Using the Ehrenberg collection. - Diatom Res. 13: 273-291.

MAnN, D.G. (1989): The diatom genus Sellaphora: separation from Navicula. - Br. Phycol. J. 24: 1-20.

Mann, D. G., Thomas, S. J. \& Evans, K. M. (2008): Revision of the diatom genus Sellaphora: a first account of the larger species in the British Isles. - Fottea 8: 15-78.

Patrick, R. M. \& Reimer, C. W. (1966): The diatoms of the United States, exclusive of Alaska and Hawaii. Vol. 1: Fragilariaceae, Eunotiaceae, Achnanthaceae, Naviculaceae. - Monogr. Acad. Nat. Sci. Philad. 13: $1-688$.

Smith, W. (1856): A synopsis of British Diatomaceae, vol. 2. - 107 pp., J. Van Voorst, London.

(C) Czech Phycological Society

Received May 2, 2008

Accepted July 15, 2008 